\title{
The Utilization of Candle Media to Improve Breathing Engineering on Solfeggio Choir Universitas Negeri Medan
}

\author{
Octaviana Tobing ${ }^{1}$, Pita HD. Silitonga ${ }^{2}$, Ningsih Linda Fiska Gulo ${ }^{3}$ \\ ${ }^{1,2,3}$ Music Education Department, Faculty of Arts and Languages, Universitas Negeri Medan, Indonesia
}

\begin{abstract}
This study aims to determine the use of wax media to improve breathing techniques at Solfeggio Choir, Universitas Negeri Medan. The purpose of this study is to describe how the use of wax media to improve breathing techniques at Solfeggio Choir Universitas Negeri Medan and to determine the obstacles faced by choir participants. Solfeggio, Universitas Negeri Medan. The theory used is the theory of utilization, vocal techniques, breathing, wax media, and choir. The method used in this research is descriptive qualitative method. The sample in this study was the Solfeggio choir, Universitas Negeri Medan. The data were collected by means of observation, interviews, documentation and literature study. Based on the results of the research conducted, it can be seen that the use of wax media for vocal breathing techniques can accelerate the understanding of members in mastering vocal breathing techniques. The obstacles experienced by the choir participants were difficulty in controlling their breathing, different skill levels of the members when practicing breathing techniques using wax media, and discomfort when using wax for the first time.
\end{abstract}

Keywords utilization; breathing technique; candle media

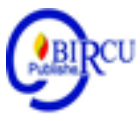

\section{Introduction}

Singing is an activity carried out by a person or a group of choirs who make sounds, have tones and lyrics that contain aesthetic values with natural expressions, so that they can convey the message of the song to the listeners. The functions of singing include: as entertainment, livelihood and also as a medium for channeling talents and creativity in the process of achieving an achievement.

Singing is different from speaking, because singing requires vocal technique. In order for a person to sing properly and correctly, knowledge and exercises are needed, such as good posture, how to breathe, how to pronounce, and how to produce a sound well. The most basic factor in singing is breathing, because the sound is processed through the friction of the breath with the vocal cords vibrated by neck resonances. The benefit of breathing exercises is to have a breath that is long enough to avoid gasping and making the listener uncomfortable. Breathing techniques have a considerable influence in creating a person's voice quality in singing.

The choir is a combination of several sound combinations, namely soprano, alto, tenor, bass and does not rule out the sharing of other sounds, such as mezzosopran, baritone or small group in certain songs. A choir is a group of singers who sing together to produce a harmonious sound that is beautiful to hear. Choirs can use instrument accompaniment or without instrument accompaniment or often referred to as acapella. 
One of the vocal techniques that play an important role in singing is the breathing technique, because breathing techniques are an important part of singing as a whole. The breathing technique that must be used in singing is the diaphragmatic breathing technique. The diaphragmatic breathing technique is generally understood as the intensity of attention by the singer to the diaphragmatic activity in gathering the air or breath used in singing.

Breathing technique is one of the main elements that must be mastered in singing and is the basis of vocal processing techniques. The inhalation that should be used in singing is the diaphragmatic breathing. In practicing diaphragmatic breathing in theory it is very easy, but in practice it is quite difficult, not everyone can do it easily and must go through regular stages of training. This made it difficult for the choir members to learn the correct diaphragmatic breathing technique. Therefore, there is a need for media to make it easier for choir members to practice breathing techniques in singing.

\section{Review of Literatures}

The theoretical basis is a description of the results of a literature that is relevant (relevant) and supports the subject matter to be studied, so that this theoretical foundation is expected to be a basis or reference or guide in solving problems that arise in research.

\subsection{Utilization}

Utilization is a process, method, act of utilizing: natural resources for development, waste for art, and others (Susilowati, 2006: 59). According to Sadiman (1986: 189) "The use of the media also needs to be properly regulated and designed. The more so if the media is a learning medium. In order for learning to be effective, the use of the media must be planned systematically ". Whether or not the use of the media is successful, it really depends on the teacher / educator as a person who plays a role in the knowledge transfer process.

From some of the above opinions, the writer concludes that utilization is a process of using a tool / media, namely wax media in the breathing techniques of Solfeggio choir participants, Universitas Negeri Medan.

\subsection{Vocal Technique}

According to Soewito (1996: 11), there are several elements that must be considered in singing, these elements consist of good posture, how to breathe, how to pronounce, and how to produce sound with good intonation which is called vocal technique. Improvement of vocal techniques is basically difficult to do if it is not trained, sharpened and tried regularly (Pramayudha, 2010: 65). However, this can be done if you use several techniques in singing which are called vocal techniques. One of the most basic vocal techniques to learn is the breathing technique.

\subsection{Breathing Technique}

One of the most important elements in singing is breathing. If we master the technique, then it will definitely be very helpful for reaching high pitches and being able to sing the song according to the song phrases that should be sung in one breath.

According to Soewito (1996: 11), breathing is the most important element in singing. There are 3 (three) types of breathing in singing, namely chest breathing, abdominal breathing, and diaphragmatic breathing. While there are 5 (five) types of breathing techniques proposed by Rahardjo (1990: 36), namely collarbone breathing techniques, rib 
breathing techniques, abdominal breathing techniques, chest breathing techniques, and diaphragmatic breathing techniques.In addition, Jamalus (1988: 50) says that there are 3 (three) types of breathing that are often used in singing. These breaths are:

- Chest Breathing

This breathing is done by introducing air into the lungs so that the lungs become bigger. This activity will appear when a person's chest looks up and down. This weakness of breathing, the lungs get tired quickly and the chest cavity is not large enough to accommodate a lot of air.

- Abdominal Breathing

This breathing is caused by the movement of the stomach that is increasingly inflated, the abdominal cavity enlarges so that air from outside fills the stomach. The chest cavity is tension free. The lungs, windpipe, lining of the voice, the tools of speech, can freely produce natural sounds. However, it does not provide a strong encouragement. This stomach breathing is not good for singing either.

- Diaphragm Breathing

The diaphragm is located between the chest cavity and the abdominal cavity. When singing, the diaphragm muscle can give a strong push to the lungs and can regulate the force of the air flow through the windpipe, vibrating the lining of the voice and out through the mouth. A good breathing for singing is diaphragmatic breathing.

As a professional singer, apart from singing, he is also required to be able to perform other attractive movements, such as dancing. When we sing and dance, it is very necessary to master high breathing techniques. That's why breathing techniques are very important for singers, so they absolutely have to be mastered properly.

Based on the three breathing techniques above, diaphragmatic breathing is the best for singing (Prier, 2004: 10). There are several signs that are used as a grip and can be felt when breathing the diaphragm (Widyastuti, 2007: 9), namely:

- Stand straight.

- Feel for the lower ribs.

- Place and slightly press the palms of the hands on the left and right, between the ribs below and the upper abdomen.

- Inhalation through the nose slowly and gently.

- Put our hands on the upper waist. Concentrate on the movement of the ribs and around the upper abdomen expanding outward.

- With a movement like the one above, we will feel the palm being pushed out.

Based on the above theory, the diaphragmatic breathing technique when applied in a choir will have good sound stability. Good breathing will affect the power, sound quality, frequency, and dynamics of the song to be sung. Here the writer wants to see whether this kind of breathing technique is found in the final research of Solfeggio Choir, Universitas Negeri Medan in the song "O Salutaris Hostia by Eriks Esenvalds".

\subsection{Media}

The word media comes from Latin, namely medius which literally means 'middle', 'intermediary' or introduction. In Arabic, the media is an intermediary or messenger from the sender to the recipient of the message. Gagne and Briggs in Azhar Arsyad (2009: 4) "media is a physical tool used to convey the content of teaching material". The use of media in the teaching and learning process can generate new desires and interests, generate motivation and stimulation of learning activities, and even bring psychological influences on student choir participants. 
According to Sutikno (2009: 106) states that, "Media is a tool used to transmit messages or information from senders to message recipients. In learning activities, media can be defined as something that can carry information and knowledge in the interactions that take place between educators and students. The understanding of learning media as above is based on the assumption that the education/learning process is identical to a communication process (Prasasti, 2019).

Sitorus (2020) states that In general, media users for communicating knowledge and information will provide several benefits to their users, namely the delivery of message content and knowledge to be standard, the learning process clearer and more interesting. Learning media are tools or components that are used to convey the message of a learning material in the learning process (Gaol, 2020).

According to Siburian (2020) the function of learning media can help facilitate learning for students and educators, provide more tangible experiences (abstract to be concrete), attract the attention and interest in learning of students, and can evoke an equalization between theory and reality. Siregaar (2020) states that Learning media are needed by students in supporting their learning process in class because media is still the main source of learning for students. Learning media function as a tool in the learning process to achieve learning objectives. In facing the challenges of advancing science and technology, the role of the learning process must also be directed at the use of existing technology.

Based on the experts above, the media is a useful tool to support the implementation and achievement of goals in learning. Likewise in utilizing a medium, namely the medium of wax in the breathing technique in singing in a choir. Candle media is useful as a tool to help the quality of the breathing technique produced by the choir members in singing.

\subsection{Candle Medium}

Candle media is a learning medium with the help of candles as a tool in assisting breathing techniques. The main thing in this study is the improvement of diaphragmatic breathing technique. According to Briggs in Rudy Susilana (2009: 6) "media is a stimulating tool for students so that the learning process occurs". This shows that media is very important in a learning process. Without the media, the concentration of choir members to learn breathing techniques is low. Therefore, candles were chosen as an effective medium to increase the focus of the choir members in learning breathing techniques. The breathing technique using wax media can be practiced in the following ways:

- Stand in the perfect posture as if to sing.

- One hand held the burning candle about an inch apart.

- One hand is placed between the lower ribs and the upper abdomen.

- Inhale using your nose, feel the movement of the ribs and around the upper abdomen expanding outward. This movement indicates that the breathing has been done correctly, namely using diaphragmatic breathing.

- Remove it slowly by concentrating on one point, namely the flame on the candle.

- The concentration here is very important because it can control the air that is released to keep it stable.

- Try to keep the flame at an angle of 30-45 degrees and the flame to remain steady for about 21 seconds or more.

- Repeat these activities as a warm-up before entering the song. 
Based on some of the quotes above, the authors conclude that the media is a useful tool to support the realization and achievement of goals in learning. Likewise in utilizing the medium of candles to improve breathing techniques in singing.

\subsection{Choir}

The choir is the simultaneous sound of many members of the choir (Simanungkalit, 2008: 44). Combined from several sound combinations, namely soprano, alto, tenor, bass and does not rule out the distribution of other sounds, namely: mezzo-soprano, baritone, contralto or small group / treble in certain songs.

The soprano voice is generally recognizable by its bright sound. This voice was light, with a lively disposition. The tone area he controls is the highest among all sound types. The alto voice has a rather dark voice that sounds deep and it is like a "heavy" voice. It is a female voice that produces low notes with deep color. The mezzo-soprano is between the soprano and the alto. Not too bright and not too heavy in the range of pitch is also between the soprano and the alto, just like the soprano in the female voice, the tenor voice in men has a bright, loud sound color. While the bass sound is "dark" with a "heavy" and "deep" disposition.

It is important for us to distinguish between reading musical notation and singing. If a choir group has just reached the stage of sounding the existing notes without being followed by musical expressions such as: dynamic contrast, tempo, articulation, frasering, etc., the choir group cannot be said to be singing.

\section{Research Methods}

\subsection{Location and Time of Research \\ a. Research Sites}

In accordance with the research title "Utilization of Wax Media to Improve Respiratory Techniques at the Solfeggio Choir, Universitas Negeri Medan."

\section{b. Research Time}

Research time and research process was carried out in August-September 2020.

\subsection{Population and Sample \\ a. Population}

The populations in this study were 24 active members of the Solfeggio Choir Universitas Negeri Medan.

\section{b. Sample}

The samples in this study were 10 members of the Solfeggio Choir Universitas Negeri Medan (3 soprano, 2 alto, 2 tenor, and 3 bass).

\subsection{Data Collection Technique \\ a. Interview}

By using interview method, the author will ask informants about how to use wax media to improve breathing techniques at the Solfeggio Choir, Medan State University and several other questions regarding the obstacles faced by the choir participants. 


\section{b. Documentation}

In accordance with this opinion, the authors use the documentation method, namely by documenting interview meetings with informants, namely members and coaches of Solfeggio Choir Medan State University.

\section{c. Observation}

Observations made by the author were to find out how the process of using wax media to improve breathing techniques at Solfeggio Choir, Universitas Negeri Medan.

\section{d. Literature Study}

The author searches and reads some literature such as books and articles that are relevant to the subject to be discussed. With this library source, it can be obtained a lot of information that helps the author in doing this research.

\subsection{Data Analysis Technique}

Based on the opinion, the data analysis stage in this research will be endeavored to deepen or interpret the data specifically in order to describe the research objectives.

\section{Discussion}

\subsection{Solfeggio Choir, Universitas Negeri Medan}

Based on the results of an interview with Mr. Lamhot B. Sihombing, M.Pd as the coach of Solfeggio Choir (interview on 11 September 2020), said that Solfeggio Choir is a choir community consisting of students from Medan State University from various departments and faculties. The participants who want to join the choir community will be selected by going through several stages.

\subsection{The Process of Using Wax Media to Improve Breathing Techniques at the Solfeggio Choir, Universitas Negeri Medan}

Through an interview conducted by the author to Mr. Dedi Lumban Gaol, as one of the Solfeggio Choir coaches (on September 15, 2020), said that the wax media was used as a tool to monitor members using the correct diaphragmatic breathing technique and as a training aid for improve diaphragmatic breathing technique. The ability and improvement of the Solfeggio Choir choir members' breathing techniques using wax media can be seen when the members sing a piece of the song O Salutaris Hostia "Bella premunt hostilia, da robur fer au xilium" by Eriks Esenvalds in one phrase for \pm 30 seconds). They sing the lyrics in the standing position of a good singer, one hand holding a burning candle, put it in front of chest level with a distance of one inch, then concentrate to control the breath that is exhaled and sing a piece of the song. If the members are able to sing the lyrics of the song without turning off the burning candle, it can be concluded that the candle medium has the benefit of helping students concentrate, regulating their breath, and improving diaphragmatic breathing techniques.

In addition, the wax media has an advantage, namely that the choir members are more focused, so it is more effective in accelerating the understanding process of the choir members in controlling the diaphragm than without the media. Without the media, the concentration of members learning to apply breathing techniques is quite low. 


\subsection{Constraints Experienced by Members of the Solfeggio Choir, Universitas Negeri Medan when Using Candle Media}

Based on the interview conducted by the author to Mr. Dedi Lumban Gaol, as the coach of the Solfeggio Choir at the Universitas Negeri Medan (interview on 17 September 2020) said the problems experienced by the choir members when doing breathing exercises using wax media, namely the discomfort when using wax for the first time due to several reasons. Choir members can not control the air out of the mouth.

\section{Conclusion}

Based on the results of the research that has been done, the authors made several conclusions including:

1. Solfeggio Choir is a choir community consisting of students from Medan State University who come from various departments and faculties.

2. To hone his singing skills and train mentally in public, Solfeggio Choir also conducts church visits every month in various churches in the city and outside the city.

3. The wax media has the advantage, namely that the choir members are more focused, thus accelerating the understanding of the choir members in breathing techniques than without the media and the use of wax media in the process of mastering the breathing technique is very effective.

4. The obstacles faced by the members of the choir when practicing breathing techniques using wax media, namely: (1) Some Solfeggio Choir members still have difficulty controlling their breath using candles, (2) The level of ability of the members varies when practicing breathing techniques using wax media, and (3) Discomfort when using wax for the first time because some members do not support the diaphragm and are less able to control the air that comes out of the mouth.

\section{References}

Arsyad, Azhar. 2014. Media Pembelajaran. Jakarta: PT. RAJAGRAFINDO PERSADA Arsyad, Azhar. 2009. Media Pembelajaran. Jakarta: PT. RAJAGRAFINDO PERSADA Okatara, Bebbi. 2011. 6 Jam BelajarTeknik Olah Vokal. Jakarta. Gudang Ilmu

Berlioz. 2007. The New Criterion. University of California. Foundation for Cultural Review

Bungin, Burhan.2007. Metode Penelitian Kualitatif. Jakarta: Kencana

Ehman, Wilhem. 1968. Choral Directing. United States of America: Augsburg Publishing House.

Gaol, R.L., and Sitepu, A. (2020). The Influence of Used Good-Based Learning Media on the Value of Chracter Education and Student's Motivation to Study. Budapest International Research and Critics in Linguistics and Education (BirLE) Journal Vol 3 (4): 1696-1703.

Hadeli. 2006. Metode Penelitian Kependidikan. Padang: Quantum Teaching. Listya, Agastya Rama. 2007. A-Z Direksi Paduan Suara. Jakarta: YAMUGER

Pramayuda, Yuda 2010.Buku Pintar Olah Vokal. Yogyakarta: BUKUBIRU

Prasasti, T.I., Solin, M., and Hadi, W. (2019). The Effectiveness of Learning Media Folklore Text of North Sumatera Based on Blended Learning by 10th Grade Students of Vocational High SchoolHarapan Mekar-1 Medan. Budapest International 
Research and Critics in Linguistics and Education (BirLE) Journal Vol 2, No (4): 480-490.

Pusat Musik Liturgi. 2011. Menjadi Dirigen II .Yogyakarta.

Rudy MY, 2008.Panduan Olah Vokal, Jakarta.Media Pressindo.

Simanungkalit.N, 2008.Teknik Vokal Paduan Suara. Jakarta: PT. Gramedia Pustaka Utama.

Sitompul, Binsar (2002). Paduan Suara Dan Pemimpinnya.Jakarta : BPK Gunung Mulia.

Sadiman, Arief S. Media Pendidikan. Jakarta: PT. RAJAGRAFINDO PERSADA

Siburian, S., Hutagalung, S.M., and Daulay, S. (2020). Development of Adobe Flash CS6 Learning Media in Short StoryBased on Learning Text of Advanced Local Community of Batak Toba Students in Tanjungmorawa. Budapest International Research and Critics in Linguistics and Education (BirLE) Journal Vol 3 (1): 591599.

Sihotang, Reyapruma Rocky. 2014. Tinjauan Penerapan Teknik Vokal dan Komposisi Aransemen Lagu pada Grup Nasyid Maidany.Medan: Skripsi Fakultas Bahasa danSeni Universitas Negeri Medan.

Siregar, A.C., Adisaputera, A., and Yus, A. (2020). The Development of Interactive Media Assisted by Macromedia Flash to Improve the Ability of Understanding the Fiction Story Information in Elementary School Students. Budapest International Research and Critics in Linguistics and Education (BirLE) Journal Vol 3, No (2): 1200-1208.

Siregar, Marito Sari. 2016. Kemampuan Paduan Suara Tuna Netra Karya Murni Choir Dalam Menyanyikan Lagu Sing When The Spirit Says Sing Karya Jesse Vaughn Di 4th Bali International Choir Festival. Medan: Skripsi Fakultas Bahasa dan Seni Universitas Negeri Medan.

Sitorus, L.S., Mardianto, and Matsum, H. (2020). Development of Powerpoint-Based Learning Media on Learning Aqeedah Morals. Budapest International Research and Critics in Linguistics and Education (BirLE) Journal Vol 3 (2): 958-964.

Soewito. 1996. Teknik Termudah Belajar Olah Vokal. Jakarta. Titik Terang.

Sugiyono.2009. Metode Penelitian Kuantitatif Kualitatif Dan R\&D.Bandung. Alfabeta.

Sugiyono. 2008. Metode Penulisan Kuantitatif Kualitatif. Bandung. Alfabeta.

Sugiyono. 2016. Metode Penelitian Kuantitatif Kualitatif Dan R\&D. Bandung. Alfabeta.

Sugiyono. 2015. Metode Penelitian Pendidikan. (Pendekatan Kuantitatif, Dan R\&D. CV Alfabeta. Bandung.

Sugiyono. 2012. Metode Penelitian Kuantitatif Kualitatif Dan R\&D. Bandung. Alfabeta.

Sadiman, Arief S. Media Pendidikan. Jakarta: PT. RAJAGRAFINDO PERSADA

Tampubolon, Amri. 2016. Penggunaan Media Backing Track Dalam Pembelajaran Gitar Pilihan di Prodi Pendidikan Bahasa Dan Seni Universitas Negeri Medan. Medan: Skripsi Fakultas Bahasa dan Seni Universitas Negeri Medan. id.m.wikipwedia.org/wiki/Pad uan-suarahttp://berlatihrmusik.blogspot.co.id/2016/ 07/peningkatan-teknik-pernafasan.html. 